\title{
Representações fílmicas de uma instituição policial violenta: resquícios da ditadura militar \\ em Tropa de Elife
}

\section{RESUMO}

O propósito deste artigo é investigar como representações fílmicas da violência e da opressão simbólica evidenciam as tensões que se estabelecem no confronto entre traficantes e policiais em ações de combate ao crime nas favelas brasileiras. Analisaremos trechos de um filme recente, Tropa de Elite (2007), no qual métodos de tortura são usados - tanto por policiais quanto pelos traficantes - para obtenção de confissões e execuções por vingança. Argumentamos que a brutalidade que rege as relações entre policiais, traficantes e moradores de favelas reafirma a naturalização de padrões simbólicos que representam resquícios das estratégias opressoras empregadas na época da Ditadura Militar. A violação dos direitos humanos revela que apesar de existirem diferentes organizações policiais no Brasil, a questão de como os policiais lidam com os cidadãos pobres e marginalizados traz à tona uma característica comum a todas elas: o abuso do poder e do uso da agressão física como forma de eleminiar um "inimigo". Metodologicamente, nossa análise está baseada na "crítica diagnóstica da cultura", tal como elaborada por Kellner (2001), enfatizando duas de suas dimensões: i) o horizonte social do filme; e ii) seu campo discursivo (análise da mensagem e de outros recursos visuais e expressivos).

\section{PALAVRAS-CHAVE}

Instituições policiais

Ditadura

Representações

Film representations of a violent police institution: traces of Military dictatorship in Elite Squad

\section{ABSTRACT}

The aim of this work is to investigate how film representations of violence and symbolic oppression evidence the tensions between police and drug traffickers in actions performed to fight crime in Brazilian slums. A recent Brazilian movie, Elite Squad (2007) shows that both police officers and criminals use methods of torture to obtain confessions or to take revenge. We argue that the brutality that drives the relationship among police officers, slum citizens and drug traffickers reaffirms naturalized symbolic oppression patterns that were used in the period of military Dictatorship in Brazil. The violation of human rights shows that in spite of the differences among various forms of Brazilian police organizations, the mistreatment given by police to poor and marginalized citizens shows something they have in common: power abuse and physical aggression as the only way to eliminate an enemy. Our analysis is based on a "diagnostic criticism of culture" (Kellner, 2001) which mainly emphasizes: a) the social horizon of the movie and b) its discursive field (analysis of the message and visual resources).

\section{KEYWORDS}

Police Institutions

Dictatorship

Representations

\section{Ângela Cristina Salgueiro Marques}

Professora do Programa de Pós-Graduação em Comunicação da FACASPER/SP/BR

angelasalgueiro@gmail.com

\section{Simone Maria Rocha}

Professora do Programa de Pós-Graduação em Comunicação da UFMG/MG/BR

smarocha@ig.com.br 
As imagens de violência transmitidas pela mídia de massa no país chamam a atenção para o crescimento da truculência policial para combater a criminalidade nos grandes centros urbanos. O imaginário social do policial como "exterminador de bandidos" é constantemente alimentado por um aparelho opressor que ainda recorre a táticas repressivas e reativas oriundas da Ditadura Militar. Essas táticas frequentemente dificultam ou impedem "a aproximação e a interação continuada entre policiais e população, enfraquecendo assim a confiança dos cidadãos em relação à capacidade de resposta da polícia" (Souza, 2001, p. 153). Para que a ação policial junto a diferentes comunidades ocorresse de modo a promover o diálogo e uma maior aproximação entre oficiais e cidadãos comuns, seria preciso questionar a cultura da violência que alimenta as instituições policiais brasileiras desde a época da Ditadura.

A ação policial herdou dessa época uma estratégia padrão de intervenção que se baseia na diretriz de "matar, de forma mais ou menos indiscriminada e encoberta, traficantes, assaltantes, sequestradores ou simples suspeitos, ignorando o veto constitucional à pena de morte" (Rondelli, 1997, p. 144). Esse tipo de conduta não só reforçaria o resgate de uma herança de violação dos direitos humanos vinda da Ditadura, mas também a ineficácia das políticas de segurança pública e do Estado para gerenciarem o crescimento da violência urbana.

Ao lado de estratégias e experiências de prevenção, as quais buscam construir vínculos de reciprocidade e confiança entre a polícia e a comunidade (Henriques, 2008), prevalecem modos extremamente violentos e hierarquizados de se combater o crime no Brasil. $\mathrm{Na}$ verdade, as organizações policiais possuem várias "frentes" para lidar com o crime: desde as ações preventivas e de proximidade (as quais buscam alterar a mentalidade dos policiais e das comunidades, ampliando a confiança entre ambos) até ações de "choque" que visam controlar, de maneira focalizada e brutal, situações consideradas de extremo risco. $\mathrm{Na}$ cidade do Rio de Janeiro, por exemplo, a ação de traficantes nos morros e favelas instaura um cenário que é constantemente associado à guerra civil. Diante desse cenário, a única estratégia possível considerada pelos responsáveis pela segurança pública é a utilização de um grupo de policiais especificamente treinados para um combate militar. $\mathrm{O}$ entendimento das peculiaridades da história institucional das diversas formas de organização policial nos ajuda a “entender as diferenças expressivas no nível de violência empregado por elas no combate ao crime. A despeito de manterem estruturas disciplinares semelhantes, elas se diferenciam no nível de tolerância em relação ao emprego da violência abusiva" (Sapori; Souza, 2001, p. 179).

Por mais que diferenças possam ser apontadas, a cultura policial tem como principal base a referência a um saber prático, resultado de experiências concretas de combate ao crime e que se disseminam informalmente entre veteranos e novatos. Muitas das decisões tomadas por policiais em seu exercício têm como referência uma mistura entre treinamento oficial, sabedorias e táticas herdadas e conhecimentos informais. Entretanto, determinadas organizações policiais expressam e irradiam com maior força uma cultura militar cunhada na época da ditadura. O Batalhão de Operações Especiais (BOPE), por exemplo, se estrutura como um verdadeiro exército, único capaz de intervir em momentos de crise e instabilidade.

\section{Nosso objetivo neste artigo é elaborar uma análise que prefende captar como as representações da violência policial no filme Tropa de Elite (2007), do cineasta brasileiro José Padilha, dão a ver aspectos que dizem respeito à influência de méfodos de tortura e de agressão física e moral, herdados da Ditadura Militar, nas práticas afuais de combate ao crime.}

Interessa-nos discutir a representação dos modos como a instituição policial brasileira e, mais especificamente, a polícia carioca, aborda e se relaciona com a população marginalizada, com os usuários de substâncias ilícitas e com os criminosos envolvidos com o tráfico de drogas na cidade do Rio de Janeiro. 


\section{Tropa de Elite: uma narrativa costurada por} estratégias de aniquilação do inimigo

Tropa de Elite mostra a ação dos policiais do BOPE, uma equipe da polícia militar treinada para combater o tráfico de drogas nas favelas do Rio de Janeiro. A narrativa é contada num ritmo acelerado, marcado por roteiro, pelo encadeamento das cenas num ritmo alucinante, pela trilha sonora - com músicas que insinuam suspense e tensão, pela montagem fragmentária e pela curta duração dos planos.

Cenas chocantes e brutais mostram o modo como o BOPE age pragmática e instrumentalmente no combate ao crime, com chegadas estratégicas e sorrateiras nas favelas, execuções a sangue frio, uso evidente de métodos de tortura para obter confissões e intimidamento dos moradores. Um trecho de uma das músicas cantadas por policiais em treinamento enquanto praticam algum exercício diz o seguinte: "Homem de preto1 qual é sua missão? Entrar pela favela e deixar corpo no chão Por isso, muitas vezes, os desfechos para os conflitos se reduzem a uma escolha: se não matar, morre. Como esclarece o Capitão Nascimento: "Homem com farda preta entra na favela para matar, nunca para morrer".

A articulação do enredo do filme é feita por um narrador que, ao se dividir entre seus dilemas pessoais e sua missão como agente institucional, busca revelar como os policiais enxergam a questão do tráfico de drogas no RJ. ${ }^{2}$ Em um primeiro plano, o filme parece reproduzir a visão de que, para que a sociedade funcione bem, para que o equilíbrio de forças seja mantido e a performatividade das instituições seja máxima, "os criminosos são inimigos a quem se deve exterminar e os usuários são financiadores hipócritas desse negócio". Mas, em segundo plano, essa visão nos parece muito simplista, uma vez que não abrange todas as facetas das práticas sociais que envolvem as interpretações que cada ator social faz de seus pares. Assim, se para os policiais "bandido bom é bandido morto", para os traficantes e moradores de favela "policial bom é policial morto ou corrupto". Nesse sentido, o filme busca também evidenciar como policiais, moradores de favelas, habitantes da cidade do Rio, traficantes, membros de ONGs que atuam junto a comunidades carentes vêemse uns aos outros e tentam conviver sob o imperativo de esquematismos simbólicos que classificam e determinam, de antemão, o tipo de relação a ser estabelecida e os seus resultados.

A violência policial retratada no filme - somada às dimensões da fragilidade da cidadania, da ausência de reconhecimento social, da injustiça e do desprezo como códigos amplamente aceitos da sociabilidade vigente - nos fornece, assim, um novo elemento de reflexão: identificar em Tropa de Elite elementos e representações que apontem para um tipo de violência que, apesar de se fazer mais evidente no plano institucional e nos modos sancionários dos aparatos de poder, também pode ser detectada no plano simbólico, onde destitui os indivíduos (seja entre policiais, seja entre traficantes) de respeito e dignidade, reificando-os e reduzindo-os a inimigos que devem ser aniquilados.

\section{Considerações metodológicas}

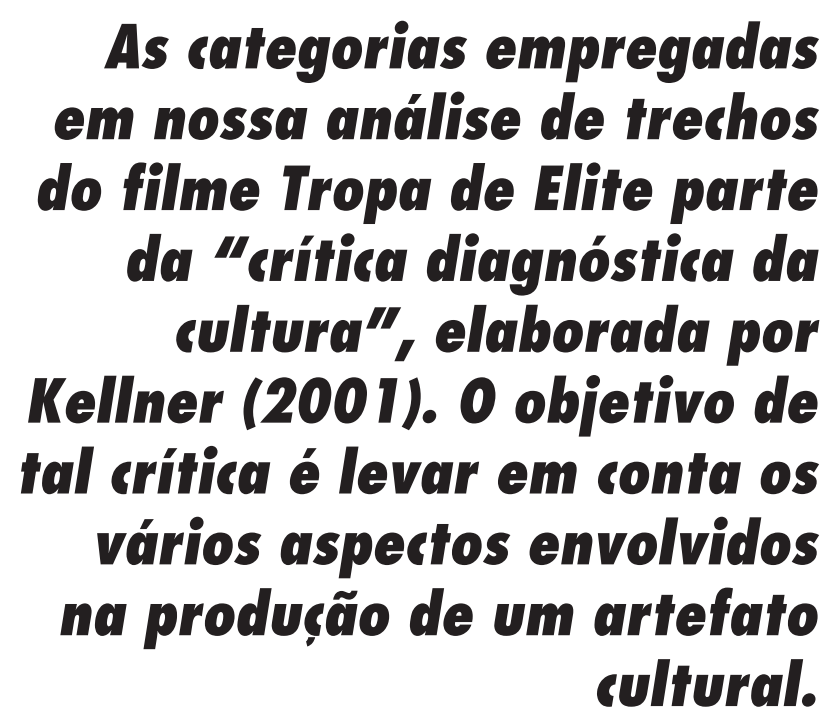

Para este autor, se queremos compreender de modo crítico a cultura contemporânea por meio da análise de produções dos media, é preciso realizar estudos que considerem o modo como a indústria cultural cria produtos específicos capazes de reproduzir os discursos sociais incrustados nos conflitos e nas lutas de uma época.

Isso significa que, para se relacionar texto e contexto, é preciso estabelecer as articulações através das quais as sociedades produzem cultura. Kellner afirma que os produtos da cultura da mídia não são puro "entretenimento inocente", desprovidos de conteúdos ideológicos, mas vinculam-se às retóricas e às lutas por dominação e poder subjacentes às sociedades, sendo também conformados pelos modos de produção midiáticos. Por isso, o autor defende a análise minuciosa de como "a ideologia é apresentada na forma de imagens, 
figuras, códigos genéricos, mitos e aparato técnico de cinema, televisão, música e outros meios [...]” (2001, p. 123).

Ao realizar tal crítica diagnóstica sobre alguns filmes hollywoodianos dos anos 1960 e 1980, Kellner lançou mão de estudos sobre ideologias, movimentos sociais e o ambiente em que surgem, adotando três categorias análise: horizonte social, campo discursivo e ação figural ${ }^{3}$. A partir delas, o autor pretendeu "descrever alguns dos modos como os textos culturais transcodificam e articulam imagens, discursos e condições sociais, ao mesmo tempo em que operam dentro de seu campo social" (2001, p. 137).

Neste artigo, pretendemos explorar duas das categorias apresentadas por Kellner: horizonte social e campo discursivo. O horizonte social pode ser descrito como aquele que se refere "às experiências, às práticas e aos aspectos reais do campo social que ajudam a estruturar o universo da cultura da mídia e sua recepção" (Kellner, 2001,p. 137). Nesse sentido, Tropa de Elite não só se inscreve em um contexto atual de produções fílmicas que retratam as periferias urbanas e os conflitos que marcam o cotidiano das favelas brasileiras ${ }^{4}$, mas também em um contexto de extrema insegurança alimentado por uma violência que, para ser contida, coloca em tensão políticas públicas de segurança destinadas à integração entre policiais e cidadãos e táticas mais agressivas e "cirúrgicas" que implicam ainda na "militarização" da ação policial.

No início dos anos 90, grande parte dos países da América Latina presenciava um lento processo político de redemocratização após o fim das ditaduras, com a subseqüente implantação das políticas econômicas neoliberais. Contudo, o enraizamento da violência no cotidiano das organizações policiais não diminuiu. A incompatibilidade entre a militarização da política e o respeito aos direitos básicos dos cidadãos somase, a partir dos anos 80, à intensa militarização do crime organizado. Fortemente armados, os traficantes abrigados nas periferias e favelas mostram habilidade no uso de armamentos variados e conhecimento de táticas de guerrilha, provavelmente aprendidas nos cárceres do período militar, quando estes criminosos eram colocados junto a guerrilheiros e outros contraventores (Santos, 1997). Aspectos como a violência e a crueldade empregada por traficantes, a relação ambígua que estabelecem com a comunidade - oferecendo-lhe uma espécie de proteção e exercendo uma função social -, o desejo de obtenção do dinheiro fácil e rápido aliado à falta de melhores perspectivas de vida, são alguns dos fatores que ajudam a compor o cenário da realidade além da tela.

Por sua vez, a categoria de análise do campo discursivo pretende, de acordo com Kellner (2001, p. 138) avaliar as imagens e os discursos cinematográficos, a música e a linguagem dos filmes, assim como seus demais recursos expressivos. Nossa intenção é destacar, em algumas sequências escolhidas de Tropa de Elite, os recursos expressivos que nos auxiliem a apreender elementos emblemáticos para a construção de uma análise de representações que, neste filme, remetem aos resquícios do tratamento que os militares, no período da Ditadura, destinavam àqueles considerados "criminosos", entre eles a tortura, agressão física e o abuso de poder.

$\mathrm{Na}$ próxima seção, abordaremos a primeira dessas categorias já na tentativa de avançar sobre qual seria o horizonte social de Tropa de Elite.

\section{Herança de códigos e táticas militares}

O Batalhão de Operações Especiais (BOPE) foi criado em 1978, após ganhar força a idéia de que a polícia militar necessitava de um grupo especial para atuar em situações de crise. Seu criador, o coronel Paulo César Amendola, de 63 anos, admite que participou, na época da Ditadura, de operações de cerco e combate, mas rejeita qualquer acusação de que tenha torturado cidadãos: "Sempre acreditei que as guerras passam e fiz o meu trabalho sem tratar ninguém como inimigo" (Barros, 2007). Contudo, os policiais do BOPE hoje sobem os morros cariocas e promovem o "extermínio" de seus opositores: aqueles que são comumente chamados de "vagabundos", "marginais", "escória social", etc. Assim como na guerra, o uso desmedido da força é validado por meio da desumanização do inimigo, que "deve" ser eliminado. Os aparelhos policiais sofrem, portanto, com as sequelas deixadas pelo abuso do poder e pelos hábitos arbitrários do Estado.

O Brasil ainda vive à sombra do Regime Militar. Se muitos se rebelaram para serem presos, torturados e exilados, muitos mais souberam não apenas se adaptar à situação como ganhar em cima deste novo sistema de vida. Há alguns anos, diante de uma notícia de violência provocada por bandidos, uma pessoa próxima soltou um "na época 
dos militares, isso não acontecia”. Realmente. Acontecia dentro de quartéis e delegacias. O comportamento de nossas autoridades de segurança é herança direta desta época. ${ }^{5}$

Mas é preciso salientar também que, se de um lado, as instituições policiais são apontadas por fazer uso desmedido, desproporcional e inadequado da violência física, de outro lado, o treinamento dos policiais também é algo que viola os direitos humanos, impondo a humilhação e a perversidade. Como aponta Balestreri (1998), em muitas academias de polícia, os policiais parecem ainda ser condicionados para alguma suposta "guerra de guerrilhas", sendo submetidos a toda ordem de maus-tratos (beber sangue no pescoço da galinha, ficar em pé sobre formigueiro, ser "afogado" na lama por superior hierárquico, comer fezes, etc.). Seguindo vários preceitos da ideologia militar, os futuros policiais são, muitas vezes, submetidos a violento estresse psicológico, a fim de atiçar-lhes a raiva contra o "inimigo". Nessa perspectiva, a organização policial na sociedade brasileira se caracteriza por um campo de forças sociais que se estrutura a partir de três posições: o exercício da violência legítima, a construção do consenso e as práticas de excesso de poder, a violência ilegítima. Os entrecruzamentos desses três vetores vão definir a função social da organização policial no Brasil na época contemporânea (Santos, 1997).

No filme Tropa de Elite, o ritual de iniciação dos oficiais do BOPE, deixa claro que os policiais enfrentam a perda de autonomia sobre o próprio corpo, e passam a ser manipulados e agredidos pelos policiais de uma hierarquia superior. A agressão e a violência física ferem a autoconfiança dos policiais que, brutalizados, passam a agir segundo a mesma linguagem através da qual foram treinados. O resultado disso é a construção de uma assídua violência policial contra pobres, favelados, negros e traficantes, atentando contra suas liberdades civis (Neme \& Cubas, 2006).

A sequência inicial do filme, com uma narrativa em off do personagem principal, o Capitão Nascimento, revela, porém, que os policiais que são treinados para lutar contra o tráfico de drogas na cidade do Rio de Janeiro não podem entrar nas favelas usando a cordialidade e a civilidade. E isso não se explica somente pelo treinamento que recebem, mas, sobretudo pelo tipo de situação que irão enfrentar. Os bandidos possuem armas de guerra, fruto de negociações com policiais ou "companheiros" de países que estão efetivamente em guerra. Os policiais sabem que serão recebidos a tiros e, portanto, preparamse para a guerra.

No Rio de Janeiro, quem quer ser policial tem que escolher: ou se corrompe, ou se omite, ou vai para a guerra. [...] Os policiais convencionais não são treinados para a guerra. [...] Eu não sou um policial convencional. Eu sou do BOPE. Na teoria a gente faz parte da Polícia Militar. Na prática, o BOPE é outra Polícia. O BOPE foi criado para intervir quando a polícia convencional não consegue dar jeito. E no Rio de Janeiro, isso acontece o tempo todo. Eu já tava naquela guerra faz tempo e tava começando a ficar cansado dela (trecho inicial do filme, narração em off do Capitão Nascimento).

A representação dos moradores de favelas geralmente enfatiza sua pobreza e seu possível envolvimento com o tráfico. A exclusão provocada pela violência simbólica originada de estereótipos e preconceitos, sobretudo aqueles reforçados pela mídia, alimenta justificativas para a violência física, uma vez que aqueles que não são reconhecidos como cidadãos tendem fortemente a ser moralmente desqualificados, desvalorizados e punidos (Rondelli, 1997; Ramos, 2007; Honneth, 2001). Nesse sentido, a violência policial relatada no filme Tropa de Elite compreende desde execuções sumárias e sem justificativas legais, matança indiscriminada, intimidação de comunidades inteiras (o que também é válido para a ação dos traficantes), até a elaboração de operações de policiamento envolvendo o uso excessivo de força.

A tortura é empregada no filme de maneira recorrente como castigo ao infrator, ao delator (no caso dos bandidos) ou como método de trabalho policial: "nesse caso, trata-se de infligir sofrimento ao outro por meio de técnicas com objetivo de obter confissões. E para tanto, os policiais contam com a autorização de seus superiores e a conivência dos pares" (Neme; Cubas, 2006, p. 324).

A ausência de reconhecimento social, o atentado à integridade dos moradores das favelas, a violência física e simbólica, a fragilidade da cidadania, a falta de respeito pelos direitos mais básicos destes indivíduos e um conjunto de representações midiáticas que os transforma em "estranhos" que ameaçam a paz, os próprios policiais e o equilíbrio do cotidiano nas grandes cidades só reforçam a tese sustentada pela polícia e pelo senso comum de que "bandido bom é bandido morto".

\section{Uma narrativa de guerra e agressão física: análise do campo discursivo}

De modo a analisar os principais elementos discursivos de violência em Tropa de Elite, buscamos apoio nos princípios da análise narratológica que, segundo Vanoye e Goliot-Lété, "visa explicar o funcionamento narrativo próprio de um filme particular, ou de uma parte de um 
filme particular" (2006, p. 40). Os autores chamam a atenção para o fato de que a análise narratológica considera que, na narrativa, o conteúdo e os recursos expressivos estão imbricados para que haja a produção de sentido. O conteúdo é dado por dois componentes não exatamente fílmicos: a história e a diegese6. Assim, ele pode estar no roteiro, na sinopse ou em qualquer outro meio que se encarregue de reproduzi-lo, inclusive no filme. No caso específico deste, os recursos expressivos como as imagens, trilha sonora, sonoplastia, etc., compõem a diegese. É no entrelaçamento do conteúdo com a expressão que se produzirá a narrativa fílmica.

Sob esse viés, "o conteúdo e a expressão formam um todo. Apenas sua combinação, sua associação íntima é capaz de gerar significação. Não é possível pretender trabalhar sobre o sentido de um filme, sem convocar de imediato e em sincronia a história e a maneira [pela qual ele é contado]" (Vanoye; Goliot-Lété, 2006, p. 42). Abaixo apresentamos um quadro que esquematiza as categorias de análise por nós elaboradas, relacionando-as com as sequências do filme a serem analisadas:

\begin{tabular}{|c|c|}
\hline \multicolumn{1}{|c|}{ Categorias analíticas } & Sequências escolhidas \\
\hline $\begin{array}{l}\text { 1) O treinamento dos policiais do } \\
\text { BOPE: a violência institucional e seus } \\
\text { códigos internos e externos }\end{array}$ & $\begin{array}{l}\text { 1'10"57 a 1'21"19 } \\
\text { Esta sequência mostra a primeira fase } \\
\text { do treinamento do BOPE }\end{array}$ \\
\hline $\begin{array}{l}\text { 2) "Bandido bom é bandido morto": } \\
\text { a chegada da polícia na favela, tratamento a 1'50"18 } \\
\text { conferido aos moradores, métodos de } \\
\text { tortura. }\end{array}$ & $\begin{array}{l}\text { Classificamos esta como a sequência } \\
\text { final na qual os policiais do BOPE invadem } \\
\text { a favela em busca do traficante que havia } \\
\text { assassinado um policial do Batalhão. }\end{array}$ \\
\hline
\end{tabular}

As cenas analisadas em cada categoria acima descritas buscam evidenciar as tensões e conflitos que conferem complexidade à narrativa fílmica, detendo-se, contudo, em alguns elementos que parecem apontar para as dificuldades de se pensar em modos de reconfiguração das relações de força que opõem, continuamente, "inimigos" desumanizados.

O Treinamento dos policiais do BOPE: a violência institucional e seus códigos internos e externos

As instituições policiais são disciplinares e disciplinadoras. De um lado, utilizam a força para superar o adversário, obter sucesso e garantir a máxima eficácia do sistema. De outro, empregam a rigidez em seus mecanismos de preparo para garantir a conformidade de seus membros aos códigos de conduta (Sapori \& Souza, 2001). O treinamento dos aspirantes a um posto no BOPE deixa entrever algumas das principais táticas disciplinadoras de corpos e mentes. A primeira pista é dada pelo cenário de guerra que ocupa a tela de fundo das tarefas conferidas aos aspirantes.

Ao longo de todo o filme, várias cenas evidenciam o modo pelo qual os policiais do BOPE encaram suas incursões na favela entendendo tal empreitada como uma invasão no campo de batalha do inimigo. Como explica Nascimento,
O nosso curso prepara os policiais para a guerra e não adianta dizer que isso é desumano. Enquanto os traficantes tiverem dinheiro para se armar, a guerra continua. Todo policial do BOPE aprende isso.

A visão militarizada do conflito supõe que "o oponente deve ser destruído" (Sapori; Souza, 2001, p. 176). Assim, organizações militares privilegiam e mantêm uma cultura repressiva que, ao invés de preparar os policiais para lidar com as diferenças em situações de conflito, ensinam-lhes técnicas funcionais de aniquilamento do "outro". Esse tipo de conduta não só reforçaria o resgate de uma herança de violação dos direitos humanos vinda da Ditadura, mas também a ineficácia das políticas de segurança pública e do Estado para gerenciarem o crescimento da violência urbana. Os policiais buscam o confronto de modo incessante, mas não se envolvem nele de modo agonístico e sim de maneira a otimizar sua ação performática e derrotar seus opositores (Neme; Cubas, 2006).

A sequência fílmica escolhida para análise apresenta momentos em que a instituição policial utiliza o poder a elas associado (e associado às suas alas hierárquicas mais elevadas) para formar e disseminar convicções pelas quais seus agentes perdem o domínio sobre si mesmos e sobre sua situação. Assim, os recrutas, logo na primeira fase do treinamento do BOPE, devem aceitar o 
consenso operacional e ritualístico do quadro simbólico em que se encontram e se sujeitar às categorizações e práticas estabelecidas.

A sequência começa com uma cena noturna, num lugar que simula o interior de uma selva. Os alunos empunham armas exibindo expressões fechadas, e recebem as "boas vindas" do comandante do Batalhão. Essas "boas vindas" constam de falas que asseguram aos recrutas que não foram convidados e que não são bem vindos ali. Em seguida, os oficiais correm em direção aos recrutas, empurrando-os, xingando-os, ofendendoos, dando-lhes tapas no rosto e gritando: "pede para ir embora! Imundo". A câmera é trêmula e parece nos colocar na ação, transmitindo a intensidade daquele momento, marcado também pelo uso de primeirosplanos focando a expressão dos personagens, ora de medo e preocupação, ora de tensão, nervosismo, angústia e ironia. O capitão Nascimento entende o início do treinamento como um rito de passagem:

"Para quem não é iniciado o BOPE parece uma seita. Mas é assim mesmo que a gente tem que ser. [...] Pra entrar aqui, o cara tem que provar que aguenta pressão. De cada 100 PM's que tentam fazer nosso curso, cinco chegam ao fim."

Quando Nascimento aborda um dos alunos, o Zero $\mathrm{Um}^{7}$, acusa-o de corrupto e diz: "Eu vou fazer o senhor desistir. Pede para sair. Pede para sair", batendo-lhe e cuspindo-lhe no rosto. Zero Um cede à pressão e declara: "Eu desisto!". E Nascimento fala bem alto: "O Zero Um desistiu!" e os demais comemoram. A maior parte das cenas ligadas à primeira fase do treinamento mostra como a ação da polícia é brutal, exemplificada pelo tom agressivo e enérgico com qual Nascimento conduz seus alunos. Os recursos da narrativa, tanto quanto sua narração - a entonação, as pausas, o ritmo e o modo como o capitão se dirige ao espectador, como "parceiro" - são utilizados para estabelecer uma correspondência com o público.

O treinamento prossegue e a ausência de respeito, de valorização da dignidade alheia e a redução dos soldados a "animais" são elementos retratados na cena em que os alunos são preparados para o almoço: todos estão de pé, em círculo, enquanto Nascimento convoca o "Xerife" do turno, o Zero Meia, e anuncia que eles teriam apenas dez segundos para o almoço. Em seguida, dois auxiliares se aproximam com uma panela cheia e derramam seu conteúdo no chão, no centro do círculo formado pelos alunos. Os alunos são convocados a comer como bichos, lutando para conseguir um punhado de comida. Não se vê, em nenhum momento, manifestações de resistência ou recusa à ação descontrolada dos superiores.

A repetição constante das diretrizes do grupo é feita através de canções. Durante uma marcha em um pântano, o Xerife puxa uma canção na qual ele faz as perguntas e o grupo responde: "Homem de preto, o que é que você faz?" Ao que o grupo responde: "Eu faço coisas que assustam Satanás!". O Xerife prossegue: "Homem de preto qual é sua missão?" E o grupo completa: "Entrar pela favela e deixar corpo no chão!"

Os códigos externos da violência institucional manifestam-se quando a linguagem que define os policiais em seu treinamento passa a ser reproduzida na linguagem utilizada pelos policiais na abordagem aos moradores de favelas e traficantes: "vagabundo", "imundo", "miserável", "escória" são alguns dos termos utilizados que caracterizam códigos desvalorizantes que são reutilizados pelos próprios policiais em suas práticas concretas. Assim, uma cadeia de desprezo e de reificação é perpetuada. Essas tensões expressas no filme revelam que o poder se reproduz como "relação", como conflito constantemente atualizado que envolve luta e submissão. As linguagens que disciplinam policiais são as mesmas que, carregadas de desprezo e injúria desqualificam e subjugam os traficantes.

\section{"Bandido bom é bandido morfo": a chegada da polícia na favela, tratamento conferido aos moradores, méfodos de forfura}

A sequência final do filme mostra os policiais entrando no Morro para capturar Baiano, o chefe do tráfico, que havia assassinado um dos membros do BOPE. Ela começa com um plano geral do morro, que se torna menos aberto, de modo a mostrar os policiais subindo a favela, suscitando no público a expectativa da captura anunciada. Essa sequência reúne três características ligadas à concepção de que, para a polícia, "bandido bom é bandido morto": a intimidação dos moradores, o uso da tortura e o abuso da violência e da autoridade.

A morte e a violência figuram no filme como a linguagem comum entre policiais e traficantes. É a imutabilidade desses códigos de sociabilidade que fazem 
com que se torne complicado promover representações que tentem alterar a leitura dos fenômenos concretos. No filme,

a violência aparece não só como mero fenômeno da agressão física, mas também como linguagem, como ato de comunicação. Não por qualquer decisão consciente de suas vítimas ou praticantes, mas por ser a expressão limite de conflitos para cuja solução não se pode contar com formas institucionalizadas de negociação política ou jurídica legítimas (Rondelli, 1997, p. 144)

Para registrar a operação de captura do Baiano e acentuar a brutalidade policial na invasão de favelas, alguns elementos expressivos da linguagem do cinema ganharam maior destaque: o uso da câmera na mão, trêmula, vibrante, por exemplo, tende a fazer com que o espectador se situe dentro da ação, ao invés de olhá-la de um ponto de vista externo. Isso aumenta a sensação de proximidade da encenação e dos personagens e contribui com uma caracterização realista. A condução feita pelo narrador também é fundamental para o encaixe entre as cenas. Ele afirma estar agindo errado, mas justifica suas escolhas reafirmando argumentos que confrontam o respeito aos direitos civis e a vingança pessoal: "O que eu estava fazendo não era certo. Eu não podia esculachar os moradores para encontrar um bandido. Mas naquela altura do campeonato, amigo, pra mim tava valendo tudo. Nada nesse mundo ia me fazer parar".

Nascimento ordena que os policiais revistem casa por casa. Em uma cena específica, um plano médio é usado para mostrar três policiais na porta de um barraco. Eles arrombam a porta e apontam as armas para uma família - um adulto e três crianças, que estão em volta da mesa almoçando. Há um corte e a cena seguinte mostra os policiais invadindo um dos quartos da casa e acordando um garoto a tapas. Aqui vale a pena destacarmos o modo como os policiais tratam os moradores, pois o que se segue é uma explícita violação dos direitos humanos: a integridade física e moral dos moradores é ameaçada por interrogatórios que mesclam ofensas e agressões. $\mathrm{Na}$ sequência, enquanto os policiais apontam armas para esse garoto, a quem acabam de acordar, o Capitão pede permissão ao garoto para revistar seu armário. O policial que acompanhava o capitão encontra um tênis de marca reconhecidamente cara e o garoto alega que o havia ganhado. E o policial afirma: "ganhou não, tu perdeu. Vamos embora!". E ele é levado para fora do barraco.

Outro subordinado ainda tenta alertar Nascimento acerca das agressões que estavam sendo feitas aos moradores e da má repercussão na comunidade, mas o Capitão contesta dizendo que havia subido para buscar "o cara" e que iria "quebrá-lo" naquele dia. O subordinado reforça que não concorda com tortura. Ignorando o conselho, o Capitão diz que ele podia ir embora, juntamente com sua equipe.

$\mathrm{Na}$ sequência, Nascimento leva o jovem que havia ganhado o tênis para o alto do morro dizendo-lhe: "Eu não quero machucar você. Eu não quero que você saia daqui machucado. Você entendeu? Cadê o Baiano?"

Já na primeira negativa do garoto, Nascimento dálhe um tapa no rosto. Daí em diante, ele é severamente torturado, com bofetadas e asfixia através de um saco plástico colocado em sua cabeça. Ao resistir, o garoto é humilhado, a ponto de o Capitão mandar que lhe tirem as calças e a cueca enquanto pega um cabo de vassoura para acertar-lhe no meio das pernas. Diante de tal ameaça, o garoto confessa o paradeiro do Baiano.

Os cortes dentro da sequência, a música de suspense e os planos que privilegiam as feições dos personagens conferem um ritmo tenso às ações, permitindo-nos depreender que os policiais estão agindo sob forte pressão e tensão. Isso nos permite perceber que, apesar de os procedimentos violentos serem rotineiramente utilizados pelos policiais em suas abordagens, eles constituem um conhecimento prático que não é assumido publicamente, causando mal-estar e exigindo "sangue frio".

A cena seguinte mostra Baiano em seu esconderijo, um dos barracos da favela, demonstrando preocupação com a aparente tranqüilidade do Morro. $\mathrm{O}$ ambiente de calmaria é interrompido pela chegada dos policiais do BOPE, que atiram nas costas do comparsa do Baiano. Baiano sobe para a laje do barraco, é acertado por um dos policiais e, em seguida, Nascimento e outro policial estão com suas armas apontadas para o traficante, já baleado e deitado no chão:

Baiano: Vamo trocar uma idéia aí chefe, vamo trocar uma idéia. Eu tenho muito o que aprender contigo. Me leva pro hospital, aí meu chefe!

Nascimento: Você já perdeu, seu filho da puta. Você já perdeu! Você vai morrer.

Baiano: $\mathrm{Na}$ cara não, chefe, para não estragar o velório funeral!

Nesse momento, Nascimento se dirige ao outro policial e ordena: "Passa que é teu!" A última cena é o 
clímax da narrativa: o policial mira o rosto do Baiano e engatilha a arma. A execução, porém, não é mostrada. Só ouvimos o barulho do tiro. Como alerta Nascimento, "não se deve aliviar e nem ter piedade".

\section{Considerações finais}

As representações encontradas e analisadas no filme revelam muito acerca das lógicas institucionais e padrões culturais naturalizados que regem as tensões e relações de poder entre a instituição policial, a população marginalizada das favelas, os usuários de substâncias ilícitas e os criminosos envolvidos com o tráfico de drogas na cidade do Rio de Janeiro.

\section{A tônica da violência} brutal, do desrespeito e da humilhação parece predominar. 0 filme põe em xeque um tipo de idealismo civil segundo o qual o papel da polícia num Estado Democrático de Direito seria o de garantir a segurança pública, concebida como um direito de fodos, ao mostrar 0 modo como a polícia trata os bandidos como inimigos.

Ao mesmo tempo, o enquadramento militarizado dos conflitos entre policiais e traficantes destitui qualquer possibilidade de uma relação moral de valorização ou reconhecimento do outro (Honneth, 2001).

O conflito aniquilador e estratégico, que aqui aparece como resquício de estratégias consolidadas e amplamente utilizadas no período da Ditadura, transforma esses atores em meros alvos, em meios para se atingir a vitória e não em seres humanos dignos de respeito e portadores de direitos. Assim, não é eliminar o conflito que soluciona o problema, mas repensar a sua natureza.
As sequências aqui analisadas nos remefem ao contexto mais amplo proposto pelo filme: a guerra entre policiais e traficantes não se reduz à violência bruta e grafuita, ela reinscreve continuamente as relações de força e poder que perpassam a sociedade brasileira.

Entremeada à guerra do tráfico de drogas está uma guerra simbólica, travada no âmbito da liguagem, das estratégias e das táticas e que segue as mudanças históricas e sociais, ora apresentando quadros inalterados (ou em retrocesso), ora apresentando tímidas melhorias nas relações entre as forças em disputa. Todavia, uma coisa é certa: essa guerra simbólica não deixa inalterados os códigos institucionais e cotidianos que moldam as desigualdades que se fazem visíveis na linguagem, nas representações e nas identidades dos indivíduos.

\section{REFERÊNCIAS}

BARROS, Jorge. Antonio. A história do homem que criou o BOPE e hoje prega a paz. O Globo, 20 out. 2007. Memória da Polícia.

BALESTRERI Ricardo. B. Direitos Humanos: Coisa de Polícia. Passo Fundo: Paster, 1998.

HENRIQUES, Márcio. S. Polícia que conversa: reciprocidade, publicidade e accountability na implantação da filosofia de polícia comunitária, Revista Famecos, Porto Alegre, v. 36, p. 40-47, 2008.

HONNETH, Axel. Recognition or redistribution? Changing perspectives on the moral order of society, Theory, Culture \& Society, Nottingham, v.18, n.2-3, p. 4355, 2001.

KELLNER, Douglas. A Cultura da Mídia. São Paulo: Edusc, 2001.

NEME, Cristina \& CUBAS, Viviane. Elite da Tropa. 
Estudos Avancado,. São Paulo, v. 20, n. 58, p. 323-328, 2006.

PRYSTHON, Ângela. F. Os conceitos de subalternidade e periferia nos estudos do cinema brasileiro. In: CAPARELLI, Sérgio; SODRÉ, Muniz; SQUIRRA, Sebastião (Org.). A comunicação revisitada. Porto Alegre: Sulina, 2005.

REIS, Carlos; LOPES, Ana Cristina. Dicionário de Teoria Narrativa. São Paulo: Ática, 1988.

RONDELLI, Elizabeth. Mídia e Violência: ação testemunhal, práticas discursivas, sentidos sociais e alteridade. Comunicaşão \& Política, Rio de Janeiro, v. IV, n. 3, p. 141-160, 1997.

ROSSINI, Miriam. Favelas e favelados: a representação da marginalidade urbana no cinema brasileiro, Revista Famecos, Porto Alegre, n. 10, p. 29-34, nov. 2003.

SANTOS, José. Vicente. Tavares. A arma e a flor: formação da organização policial, consenso e violência. Tempo Social, Rev. Sociol. USP, São Paulo, v. 9, n.1, p. 155167, mai. 1997.

SAPORI, Luis. Flávio.; SOUZA, Barnabé Silas. de. Violência policial e cultura militar: aspectos teóricos e empíricos. Teoria \& Sociedade, Belo Horizonte, n. 7, p. 173-214, 2001.

SOUSA, Ana. Paula. Herói Torturador. Revista Carta Capital, n. 465, 10 out. 2007.

SOUZA, Elenice. Organização policial e os desafios da democracia, Teoria \& Sociedade, Belo Horizonte, n. 7, p.151-172, 2001.

VANOYE, Francis; GOLIOT-LÉTÉ, Anne. Ensaio sobre a análise fílmica. 4. ed. Campinas: Papirus, 2006.

\section{NOTAS}

${ }^{1}$ Referência ao uniforme do BOPE: uma farda preta ao invés de azul (que é usada pela polícia militar comum).

${ }^{2} \mathrm{O}$ fato de o narrador ser o Capitão Nascimento pode levar ao entendimento de que o seu modo de pensar seja típico de todos aqueles que integram o BOPE. Sousa (2007) alerta para o perigo dessa confusão: "Cenas de tortura explícita, como as de sacos plásticos sufocando gente, não necessariamente ajudam a explicar o modo de pensar da polícia."

${ }^{3}$ A categoria ação figural diz respeito às dimensões da recepção, mostrando os desdobramentos sociais dos filmes de acordo com o contexto do público; evidenciando as afetações sociais da cultura da mídia. Uma análise que se dedique a tais aspectos não será contemplada em nosso trabalho, uma vez que o problema de pesquisa circunscrito a este artigo não envolve uma investigação dessa natureza.

${ }^{4}$ A partir dos anos 90 são inúmeras as produções que elegeram as favelas e periferias urbanas brasileiras como o cenário privilegiado de suas tramas. Os filmes produzidos no final dessa década parecem levar em conta todas as mudanças ocorridas no cenário sóciopolítico e econômico ocorridas desde então. E um dos aspectos mais marcantes desses filmes é a encenação da violência urbana e criminal e a brutalidade. Filmes como Como nascem os anjos (1996), Notícias de uma guerra particular (1997), Cidade de Deus (2001), O sequestro do ônibus 174 (2002) trazem à tona o modo como os personagens estabeleceram sua ligação com o mundo do crime e adquiriram proeminência a partir de seus delitos e atos infracionais (Prysthon, 2005; Rossini, 2003).

5 Disponível em: <http://www.interney.net/blogs/ filmesdochico/2007/10/09/tropa_de_elite_1/ >. Acesso em: 21 nov. 2009.

${ }^{6}$ Designa o universo espaço-temporal no qual se desenrola a história. Ela é "o universo do significado, o mundo possível que enquadra, valida e confere inteligibilidade à história" (Reis; Lopes, 1988, p. 27).

${ }^{7}$ Os policiais do BOPE jamais mencionam o nome de seus colegas. A substituição do nome pelo número tem como objetivo proteger a identidade dos policiais quando estão em ação. 